\title{
Headship Of Professional Bodies In The Built Environment: The Challenges Facing The Female Gender.
}

\author{
O. OSUBOR (FNIQS, RQS)
}

\begin{abstract}
The United Nations have since 1975, taken special interest in the development of the women/girl child through initiatives, strategies, policies, and programmes. One of such is the Fourth World Conference on Women in Beijing China, 1995. The aim of that conference was to advance the development, empowerment and equality of the female gender with their male counterpart. The full impacts of these efforts remain to be maximized in the headship of professional bodies in the built environment by women in Nigeria? The emergence of the first female national president of the Nigerian Institute of Quantity Surveyors in November 2015 prompted the need for this study. The aim of this paper is to investigate the interest of the female gender in governance and headship positions. Data for enrolment and graduation of females in quantity surveying from 2005 to 2015 was collected from four higher Institutions of learning. Descriptive statistics and percentages were used to analyze data collected. Findings showed increase in the enrollment and graduation of the female over a ten year period. The monotony and dominant posture of men, tradition, and politics of number in favour of men were some factors that discourage women from rising to headship positions. However, since one of the advantages of open tendering is the discovery of hitherto hidden and unknown talents, it follows that unless women are given opportunity, those of them that have innate abilities and potentials in governance and administration may never be discovered. The paper advocates increased career enlightenment and membership drive, a quota and zoning arrangement of appointments for female gender into positions/offices at chapter and committee levels and probable review of the constitution.
\end{abstract}

Keywords: Female, Gender, Quantity Surveying, Headship, Professional bodies,

\section{Introduction}

The building activity involves several disciplines and professions some of which include Architecture, Civil, Electrical and Mechanical Engineering, Quantity Surveying, Building and Town Planning etc. The regulation and supervision of the activities of the profession and professionals is the responsibility of respective professional bodies headed by presidents/chairmen. Men have always dominated the headship of these bodies. Some female/women have tried to break the male monopoly of headship of these bodies but it has always been a difficult task. It is even obvious that there are some professional bodies in the built environment in Nigeria that have never produced a female head/chairman/president. The emergence of the first female national president of the Nigerian Institute of Quantity Surveyors (NIQS), one of the professions in the built environment, in November 2015 prompted the need for this paper. Was it accident? Are there cultural, religious, traditional, written or unwritten constitutional policies that have hitherto precluded/hindered the female gender from aspiring to the position of headship of the professional bodies? For example, what are the chances of producing a next female president in the quantity surveying profession or a female to succeed the present female president as it has been the case with the male counterpart? These questions form the basis upon which this topic is discussed. The aim of this paper is to activate and expose the female gender to take interest in governance/headship of professional bodies in the built environment. The objective include investigating the enrolment and graduation of the girl child in educational pursuit of the quantity surveying profession pursuant to a foundational requirement for qualification for membership of the Institute and eligibility to vote and be voted for.

\section{Related Literature}

It is claimed that Women have always been relegated to the background and are in minority, quantity surveying profession inclusive (Otokhure, 2015). In line with the Traditional African gender theory Skeggs (1997), women are considered less important to their male counterpart such that they are relegated to the upkeep of homes, to oversee the affairs and activities at home. For example, Ojo (1997) observed that only about $6.2 \%$ of those in formal employment in 1986, of the rank of Managing Director/General Manager are women. The Nigerian Institute of Quantity Surveyors (NIQS) was founded in 1969 by a group of Nigerians who trained, qualified and practiced in the United Kingdom but who upon returning to Nigeria sensed the urgent need to develop the profession of quantity surveying in Nigeria by establishing a parallel body to the Royal Institution of Chartered 
Surveyors of United Kingdom (niqs.org.ng, 2016). Of all the founding members/fathers of the profession, there was no woman among them. Records from the first university in Nigeria to offer quantity surveying programme, Ahmadu Bello University, Zaria, reveal that there was only one female among the 14 pioneer students that graduated with Bachelor of Science (Honours) in quantity surveying in 1974 (Inglis, 1975).It is not in doubt in recent times, that both in training, education, practice and other spheres of endeavor, the women folk are courageously challenging and gaining acceptance in previously male dominated activities, professions and positions. From the positive side there are female pilots, scientists, soldiers, astronauts, medical doctors, and politicians while on the negative side there are also female drug peddlers, kidnappers, armed robbers, suicide bombers and so on. It is a common knowledge now that "what a man can do, a woman can do, even better". To champion the cause of the women folks, the United Nations organizes World Conference on Women every five years with effect from first conference in 1975 in Mexico, Second in Copan- Hagen in 1980, third in Nairobi in 1985 and fourth in Beijing, China in 1995. The Fourth World Conference on Women at Beijing China was significant because it focused and specifically addressed gender equality (www.UNWomen.org). The goal of the conference was to foster empowerment and women equality with men. Some policies and organizations have sprung up to champion women empowerment, some include their greater participation in building and construction activities and related industries, to enable women reach their highest potentials. In Nigeria, the famous Better life for the rural women 1987, World Bank Gender Action Plan (2007 - 2010), Millennium Development Goal (1990 - 2015), Women for change initiative (2011), UNCED United Nations conference on economic Development (1992), Global Action for Women Towards sustainable and Equitable Development (1993) are few of the examples, but the impact of these initiatives remain to be seen in the headship/practice of women in the professional bodies in the built environment in Nigeria. A bill for the equality of women with men (2016) is presently before the eight senate of the federal republic of Nigeria. However, it is of note the women folks have produced national presidents and prime ministers of nations well before the first world conference on women in Mexico 1975. Some women have held headship positions of some of the professional bodies but that has not been sustained quite unlike the men folks who have continued to head the bodies back to back. There are no records of any professional body that has produced a female president twice in its life and the question begging for answer is which professional body will or can break the jinx. For most professional bodies the men folk have had a fair share of headship and the need for era of change lies with the women. There has been a significant enlightenment and increase in the awareness and registration of the girl child at all levels of academics in educational institutions. There are no restrictions to the areas of disciplines or programmes the female can pursue but despite this, in a recent survey (NBS 2010), by the distribution of employed persons by activity and gender, the building and construction industry represents only $2.55 \%$, (Men accounting for $2.35 \%$ and the women a paltry $0.21 \%$ ) as shown in Figure 1. Figure 1 also shows Agriculture and Wholesale and Retail trade sectors as the most vibrant sectors.

Figure 1

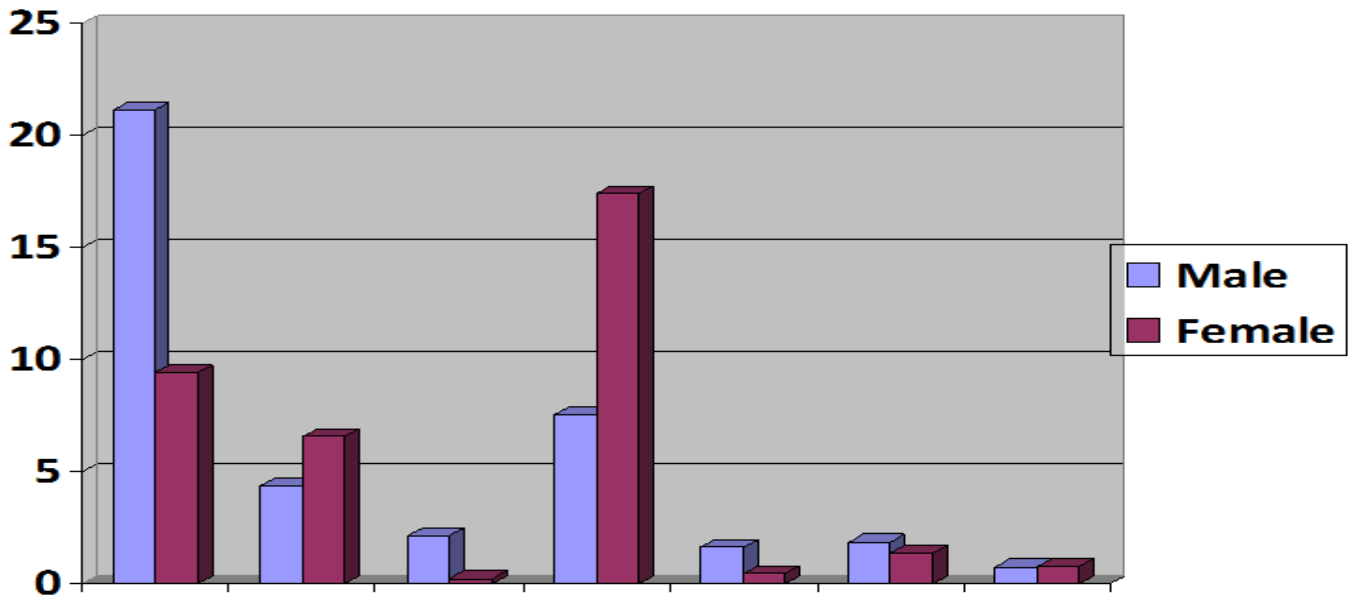

\begin{tabular}{|l|l|l|l|l|l|l|l|}
\hline & $\begin{array}{l}\text { Agricu } \\
\text { lture, } \\
\begin{array}{l}\text { Forestr } \\
\text { y and } \\
\text { Farmin } \\
\text { g }\end{array}\end{array}$ & $\begin{array}{l}\text { Manufa } \\
\text { cturing }\end{array}$ & $\begin{array}{l}\text { Buildin } \\
\text { g and } \\
\text { Constru } \\
\text { ction }\end{array}$ & $\begin{array}{l}\text { Wholes } \\
\text { ale and } \\
\text { Retail } \\
\text { trade, } \\
\text { Repair }\end{array}$ & $\begin{array}{l}\text { Admini } \\
\text { stration } \\
\text { and } \\
\text { Support }\end{array}$ & $\begin{array}{l}\text { Educati } \\
\text { on }\end{array}$ & $\begin{array}{l}\text { Human } \\
\text { Health } \\
\text { and } \\
\text { Social } \\
\text { work }\end{array}$ \\
\hline Mal & 21.14 & 4.33 & 2.15 & 7.51 & 1.60 & 1.84 & 0.74 \\
\hline
\end{tabular}




\begin{tabular}{|l|l|l|l|l|l|l|l|}
\hline e & & & & & & & \\
\hline $\begin{array}{l}\text { Fe } \\
\text { mal } \\
\text { mal }\end{array}$ & 9.43 & 6.57 & 0.21 & 17.42 & 0.43 & 1.37 & 0.78 \\
\hline
\end{tabular}

Source:Culled from National Bureau of Statistics - July 2010

Even within the UK, construction has an unenviable status as being the industry with the lowest representation of women according to Dainty, Bagihole, Ansari \& Jackson (2004). It is claimed that the construction workplace presents a challenging and hostile environment for nontraditional entrants and attitudinal barriers. Also the discriminatory behavior perpetrated by the dominant male workforce is commonplace. Surprisingly women seem to make up about 50\% of Nigeria population (NBS 2010, William 2015) It has also been reported that gender disparity in the industry is shockingly poor as women make up just $11 \%$ of the entire workforce (Martin 2014).Trend of women in quantity surveying in Nigeria The first problem facing the quantity surveying profession in Nigeria is that of obscurity or lack of publicity. Compared to the older professions in the built environment in Nigeria, very little or nothing is known about the quantity surveying as a course of study or profession in the public domain. A little boy on the street in an urban town can tell who a medical doctor, Architect, Engineer is and what they do. The same cannot be said of the Quantity Surveyor. Quantity surveying profession is both young and battling for recognition. According to Martin (2014) and (https//www.fgould.com.articles.women), during college days, construction was not a feature in the career programme. Very little was known about the role of Quantity Surveying. The situation began to change when 'The Smith Institute' presented a report titled 'Building the future'; women in construction. The report claimed that $11 \%$ of construction workforce is female and highlighted what must be done to remedy the situation, improve her image and address inequality. This has prompted the Nigerian Institute of Quantity Surveyors both at the national and State levels to embark on career enlightenment in public secondary schools to promote awareness and public enlightenment of the profession. Of all the founding fathers/pioneer of the profession who arrived from Britain and started the profession in 1969, there was no woman among them. The first national president of the institute was Chief G. A. Balogun (Fniqs), the first chartered quantity surveyor in Nigeria was Chief. Emeka Nwogwu (Fniqs) in 1976, the first woman to become a fellow who incidentally is now first female president of the institute obtained fellowship in 2003, some 27 years after. The list of registered practicing firms in 2016 posits that there are not more than ten consulting/firms whose principal partners are female out of a total of about three hundred and ninety five firms whose principal partners are males (www.ngex.com, 2016, NIQS AGM report, 2016). According to Williams (1991), the profession will continue to change in many ways. The change is noticeable in the rapid proportion of women being attracted into the profession. In 1990, the ratio of qualified men to women was 80:1, widening the picture to include students and probationers the ratio dropped to about 30:1 indicating a sharp increase in the women joining the profession.

In Nigeria, early indications for the ambition and aspiration of women into headship positions in quantity surveying profession emerged when for the first time, a female emerged as the chairperson of the largest state chapter of the NIQS - Lagos Chapter,(2014-2016), the same situation occurred in Delta (2015 - 2017), Plateau (2015- 2017), and Akwa Ibom chapters (2015-2017) respectively. Then the biggest came on November 2015 when a woman emerged the National President of the NIQS. The activities witnessed in the institute since November 2015 supports the opinion of Smith (1988) who listed one of the benefits of open tendering to include the discovery of hitherto hidden or unknown talents. Within the same period, a Nigerian female quantity surveyor Mrs. Babalola, bagged the first female professor of quantity surveying, from Obafemi Awolowo University, Ile Ife, (2015). She is the first female professor of quantity surveyor in the whole of Africa, Otohkure (2015): and also doubles as the chairperson of Women Association of Quantity Surveyors (WAQSN), a Women group of the institute formed to further women concerns. Otokhure (2015) was quoted during inauguration s saying that in order to be relevant in a changing world, women quantity surveyors have been called upon to embrace dynamism by pursuing the highest standard of professionalism in their field of practice in spite of challenges peculiar to their gender. Babalola (2015) justify the perception that the construction industry has always been viewed as male dominated and affirmed that the catchword for her tenure would be "Risk positive change for dynamic impact".

\section{Nigerian Institute of Quantity Surveyors Constitution}

The emergence of the first female national president of the NIQS followed due and proper constitutional process. Even though the constitution was drafted by the male, there is nothing in the constitution that shows bias against the female genders opportunity to rise to such position. By the provisions of The Nigerian Institute of Quantity Surveyors constitution 2015(as amended), the route to position of national presidency flows through a democratic election/voting. It commences by an election into office of Vice President, progressing/graduating to Deputy President and then to Presidency every two years during a biennial conference. The constitutional 
requirement for eligibility for election to the position of national president of the Nigerian Institute of Quantity Surveyors for presidency is restricted to members of the grade of fellow (NIQS Constitution, 2011). In addition to being a fellow, there are other additional requirements for eligibility for the post of national president. Some of these are: being a fellow of not less than 10 years, obtaining the highest/maximum number of votes in a general election, required to have held office at chapter/National Executive Committee, progression in office/position from Vice President to Deputy President and then to President in a minimum of 6 years among other requirements. The above requirements are not mandatory at chapter and committee levels. The current female national presidents citation reveals the following: academically brilliance, possesses a sound university degree beating male classmate students in the class at the time, have held several headship positions of responsibility, has over 36 years continuous work experience in top management in the building and construction industry and owns a practice firm, a building and engineering construction company that employ male professional staff, the first female Quantity Surveyor in the Northern Region of Nigeria, first female chapter chairperson, founding and chairperson of Women Association of Quantity Surveyors in Nigeria (WAQSN), and the first person to be elected into the position of National Deputy President unopposed and more importantly emerged as president based on merit and not necessarily on gender sentiments. Observers are quick to note that in the present executive committee 2015-2017, chaired by a female president, there is no other elected female member of the executive committee except representatives as chairmen of chapters and Women Association of Quantity Surveyors in Nigeria (WAQSN). For the present Deputy and Vice President to serve out their tenures of two years each implies that in the next six years no female is likely to rise to office of the president unless there is a constitution review or other changes necessitated. A look at some of the prominent professional bodies in the built environment reveals that some women have at some point taken up the challenge to rise to headship of their professional bodies. The Nigerian Society of Engineers (NSE) founded in 1958 has produced its first and only female president in $1973-1974$ (www.nse.org.ng), the $18^{\text {th }}$ president of the society in the 58 years of the Institute. It is interesting to know that the first female president of the NSE emerged well before the first International Conference on women in 1975 and no other female president has emerged since then. The Nigerian Institute of Architects (NIA) founded in $1^{\text {st }}$ April, 1960 has also produced its first and only female president in $2001-2003$, in its 56 years of establishment (www.nigerianinstituteofarchitects.org, leadership.ng/business, 2016). The Nigerian Institute of Quantity Surveyors founded in 1969 has just produced her first female president the $22^{\text {nd }}$ president of the institute after 55 years of establishment. It remains to be seen when the next female president will emerge. There are no available records to show that one of the oldest professional bodies, the Nigerian Institute of Surveyors (NIS) founded in 1934, and the Nigerian Institute of Estate Surveyors and Valuers established in 1969, Patunola-Ajayi (2016) have produced a female president. The Nigerian Institute of Surveyors (NIS) was founded in 1934 as "Licensed Surveyors Association", under the chairmanship of the late Nationalist Hebert Macaulay. In the 1960 the name changed to 'Land Surveyors Association of Nigeria'. The present name Nigeria Institute of Surveyors was adopted in 1966 with Surveyor Olumide as first president. The profession of quantity surveying in Nigeria is practiced along the same pattern of her parent body The Royal Institution of Chartered Surveyors (RICS) in the United Kingdom (www.niqs.org.ng, 2016). A look at the parent bodies of the professional bodies reveals a similar trend. For example, Louise Brook Smith became the first and only female president of the Royal Institute of Chartered Surveyors in 2014 in its 146 years of history (www.birminghampost.co.uk.business, Bishop, 2014). Royal Institution of Chartered Surveyors has over 118,000 members across the world. Louis Smith Brook during acceptance speech stated that her election was based on individual merit and not because of gender. The Royal Institute of British Architects (RIBA) was founded in 1834 (www.architecture.com/RIBA). It took the Royal Institute of British Architects one hundred and fifty seven years to produce its first female president. The first female president of The Royal Institute of British Architects is Joyce B. Deans from 1991 - 1993 (www.rias.org.uk). Another woman, Ruth Reed, became president of the Royal Institute of British Architects 2009 - 2011 (www.google.com.ng) and also stressed that her choice was on merit and not because of gender (Bishop, 2014). Angela Brady was president from 2011 to 2013 (www.bradymallalieu.com) and the current president Jane Duncan 2015 to 2017 (www.architecture.com/RIBA). This certainly appears an exception and an encouragement on the goal of the World conference on Women in Beijing China 1995 even though information about the gender distribution of the RIBA could not be sourced at the time of this study.

\section{Factors that discourage the female genders aspiration for headship positions}

It was in 1920 that women first entered the quantity surveying profession after the sex disqualification Act 1919 permitted them to qualify as surveyors (Howard, 2016). Irene Martin and Evelyn Perry were the pioneer surveyors. Irene (OBE) qualified as professional Associate in 1922 while Evelyn qualified in 1923. Irene became fellow in 1931 while Evelyn in 1937. They both formed partnership 'Barclay and Perry. From 1980 1989 the number of female chartered surveyors had increased from $1 \%$ to $3 \%$ of total membership. But by 1999 , 8000 out of 100,000 memberships were women. In 2012, $13 \%$ of Global chartered surveyors and $27.1 \%$ of 
students in the UK were female (Howard, 2016). Although this shows a slight improvement but the rate of growth is not very remarkable or impressive.

A survey of 599 male and 491 female students in Western Cape Province in South Africa reveal the following factors affecting career choice. They include Salary, working conditions, opportunities for promotion and life learning as most important factors whereas family tradition and peers were the least factors (Nicholas and Theodore, 2010). Some of the challenges faced by women in meeting up with their profession include family responsibilities, stereotyping women as unsuitable for the industry, insufficient networking and inadequate professional development. (Otokhure, 2015)

\section{METHODOLOGY}

For the purpose of this study, four polytechnics offering quantity surveying, one from each of four geo political zones out of the six geo political zones in the country, was selected based on convenience and the researcher's ability to access admissions and examinations records. Disruption of academic calendar programme and insecurity factors made it difficult to obtain data from the remaining two geo political zones. The bias and dichotomy between polytechnic and University education by Nigerians as regards to enrolment and graduation was not taken into consideration. The researcher had interactions with the Heads of Department of the selected schools at several professional forums that cooperated and volunteered information during the study. Data of admission and graduation over a ten year period 2003 - 2015 was cumulated, tabulated and analyzed using descriptive statistics and percentages. Total enrolment and graduation of the female students and including graduation rate was computed. Membership strength of quantity surveyors in Nigeria in 2015 by grade and gender was also obtained from the NIQS secretariat.

Table 1: School enrollment and graduation records from four Polytechnics: by gender Secondary Data extracted from School records of four polytechnics, 2016

\begin{tabular}{ccccccccccccc}
\hline \multicolumn{1}{c}{ Enrolment } & \multicolumn{1}{c}{ Graduation } \\
\hline Year & Male & $\%$ & Female & $\%$ & Total & $\%$ & Male & $\%$ & Female & $\%$ & Total & $\%$ \\
$2005 / 2006$ & 156 & 77 & 47 & 23 & 203 & 100 & 133 & 77 & 39 & 23 & 172 & 100 \\
$2006 / 2007$ & 169 & $\mathbf{8 0}$ & 43 & 20 & 212 & 100 & 144 & $\mathbf{8 0}$ & 37 & 20 & 181 & 100 \\
$2007 / 2008$ & 161 & 69 & 73 & 31 & 234 & 100 & 149 & 69 & 66 & 31 & 215 & 100 \\
$2008 / 2009$ & 161 & 71 & 67 & 29 & 228 & 100 & 149 & 73 & 56 & 27 & 205 & 100 \\
$2009 / 2010$ & 163 & 68 & 75 & 32 & 238 & 100 & 143 & 68 & 66 & 32 & 209 & 100 \\
$2010 / 2011$ & 136 & 67 & 68 & 33 & 204 & 100 & 131 & 69 & 59 & 31 & 190 & 100 \\
$2011 / 2012$ & 141 & 62 & 86 & 38 & 227 & 100 & 131 & 63 & 76 & 37 & 207 & 100 \\
$2012 / 2013$ & 134 & 64 & 76 & 36 & 210 & 100 & 124 & 64 & 70 & 36 & 194 & 100 \\
$2013 / 2014$ & 150 & 62 & 92 & 38 & 242 & 100 & 136 & 61 & 86 & 39 & 222 & 100 \\
$2014 / 2015$ & 168 & 68 & 80 & 32 & 248 & 100 & 159 & 67 & 78 & 33 & 237 & 100 \\
Total & 1539 & & 707 & & 2246 & 100 & 1399 & & 633 & & 2032 & 100 \\
\hline
\end{tabular}

Table 2: Graduation Rate (\%) for Male and Female

\begin{tabular}{|c|c|c|c|c|c|c|}
\hline \multirow[b]{2}{*}{ Year } & \multicolumn{2}{|c|}{ Enrolment } & \multicolumn{2}{|c|}{ Graduation } & \multicolumn{2}{|c|}{ Graduation Rate } \\
\hline & Male & Female & Male & Female & Male & Female \\
\hline $2005 / 2006$ & 156 & 47 & 133 & 39 & 85 & 83 \\
\hline $2006 / 2007$ & 169 & 43 & 144 & 37 & 85 & 86 \\
\hline $2007 / 2008$ & 161 & 73 & 149 & 66 & 93 & 90 \\
\hline $2008 / 2009$ & 161 & 67 & 149 & 56 & 93 & 84 \\
\hline $2009 / 2010$ & 163 & 75 & 143 & 66 & 88 & 88 \\
\hline $2010 / 2011$ & 136 & 68 & 131 & 59 & 96 & 87 \\
\hline $2011 / 2012$ & 141 & 86 & 131 & 76 & 93 & 88 \\
\hline $2012 / 2013$ & 134 & 76 & 124 & 70 & 93 & 92 \\
\hline $2013 / 2014$ & 150 & 92 & 136 & 86 & 91 & 93 \\
\hline $2014 / 2015$ & 168 & 80 & 159 & 78 & 95 & 98 \\
\hline
\end{tabular}

Source: Graduation rate computed from Table 1

Data Analysis and Discussion

Total number of students admitted into quantity surveying course in the four polytechnics schools selected for study from 2005/2006 to 2014/2015 academic sessions is 2246 made up of (1539 males and 707 females). Male 
accounting for $68.52 \%$ while female account for $31.48 \%$. a ratio of approximately $1: 2$. The number of graduating students is 2032 made up of (1399 males and 633 females), and in what looks like a coincidence, the trend/pattern of admission was retained at graduation, $68.52 \%$ male compared with $32.48 \%$ female. From table 1 , it can be deduced that while male enrolment declined from $80 \%$ in $2006 / 2007$ to $68 \%$ in $2014 / 2015$, female enrolment grew from $23 \%$ in 2005/2006 to 38\% n 2013/2014. Table 1 also shows that total female enrolment in the schools investigated rose steadily from a low 43 in 2006/2007 session to a high 92 in 2013/2014, an increase of over a hundred percent. The total graduation rose from a low 37 in 2006/2007 to a high 98 in 20013/2004. This confirms the view held in the literature review. The graduation rate rose steadily from 83\% in 2005/2006 to 98\% in 2014/2015 session. It can be observed that at any given time, the total number of enrolment and graduation of males are more than those of the female. Total male enrolment is 1539 compared to total female enrolment of 707, and total male graduation is 1399 compared to total female graduation of 633. But table 2 is an indication that the number and percentage contribution of the female into the pool of the Nigerian Institute of Quantity Surveyors are increasing.

Table 3: NIQS: Membership strength by grade and gender

\begin{tabular}{lcccl}
\hline Membership grade & Male & Female & Total & \% of female \\
\hline Fellow & 293 & 13 & 306 & $4.25 \%$ \\
Member & 2819 & 302 & 3121 & $9.68 \%$ \\
Probationer & 2702 & 515 & 3217 & $16.01 \%$ \\
Technician & 308 & 10 & 318 & $3.14 \%$ \\
Student & 987 & 175 & 1162 & $15.06 \%$ \\
Total & 7109 & 1015 & 8124 & $12.49 \%$ \\
\hline
\end{tabular}

Source: Nigerian Institute of Quantity Surveyors (Membership Diary) 2016.

Table 3 shows that only about $4.25 \%$ of population of Fellows are females. This poses a difficult situation for the emergence of a female to emerge as president/head of the Institute judging by the politics of number. This is the more reason the present female president must be commended especially having emerged as president based on personal merits and not on gender fiat. The rules that govern the operations in a civilized entity are the constitution and can only be amended or reviewed in accordance with the provisions of that constitution. The constitutional requirement for eligibility for election to the position of national president of the Nigerian Institute of Quantity Surveyors for presidency is restricted to members of the grade of fellow (NIQS Constitution, 2011). In addition to being a fellow, there are other additional requirements for eligibility for the post of national president. Some of these are: being a fellow of not less than 10 years, obtaining the highest/maximum number of votes in a general election, required to have held office at chapter/National Executive Committee, progression in office/position from Vice President to Deputy President and then to President in a minimum of 6 years among other requirements. The above requirements are not mandatory at chapter and committee levels. Since the first and present female national president started career at chapter, WAQSN and committee levels, it is possible to encourage female participation at chapter and committee levels by an arrangement of zoning certain slots/percentage of offices to the female gender so as to expose, encourage and arouse their interest in the administration/governance and so as not to make the institute an only/all male affair.

\section{Conclusion}

From 2005/2006 session to 2014/2016 sessions, the number of female gender taking into quantity surveying has witnessed a steady growth and the same applies to the number of females graduation. The graduation rate has also steadily grown within the same period under review. It is a clear indication that more women are now taking to quantity surveying than previously. However, graduation from a higher institution is not the only requirement for eligibility for membership into the professional body, rather a starting point in the professional ladder. With a steady and continuous growth in women enrolment, graduation and participation, the chances of headship is bound to improve over time. The constitutional requirement for the position of national president of the Nigerian Institute of Quantity Surveyors for presidency is restricted to membership of the grade of fellow. With only about $4.25 \%$ of population of Fellow, poses a slim situation for the female to emerge president judging by the politics of number. Requirements for emergence of national president membership of the grade of Fellow, minimum of 10 years on the fellows grade, obtaining maximum number of votes cast in an election, must have held office at chapter level, and stage by stage progression in office/position from Vice President to Deputy President and then to President. Not many female quantity surveyors may be eligible to contest election based on their membership representation compared to their male counterpart unless some arrangements are accommodated. 


\section{Recommendation}

Leaning on the results of the analysis and observations, that there is increase in the enrolment and graduation of the female gender in the quantity surveying profession, the following recommendations become necessary.

1) Career enlightenment and membership drive for the female gender require to be continued and intensified at all levels of the profession,

2) Consider a principle or memorandum of understanding that allows/allocates certain slots or percentage of appointment positions/offices to the female gender as a platform to encourage gender friendly environment in the professional bodies.

3) Consider a review of the constitution at chapters and committee levels to accommodate zoning and policy crafting as an initial step to expose and encourage the female gender to take interest in headship/governance.

4) Since the chairman of Woman Association of Quantity Surveyors of Nigeria (WAQSN) is by election, the constitution can be reviewed to allow the chairman of WAQSN as an elected member of National Executive Committee.

\section{Reference}

[1]. Bishop, A. (2014). First female RICS president Louise is first female president in 146 years.Http://www.opp.today/louise Accessed 7th July, 2014

[2]. Dainty, A. R. J., Bagilhole, B. M., Ansari, K. H. \& Jackson, J.(2004). Creating Equality in the Construction Industry: An Agenda for Change for Women and Ethnic Minorities

[3]. Howard, A. (2016). Women in Surveying, 1920 -date. RICS at 150.Http://www.rics.org. Accessed 6th une, 2016.

[4]. Inglis, T. L. (1975). Scotland Aids QS Development in Nigeria, Project Scotland, September 3 pp15First female president of Nigerian Institute of Architects (2016), Http://www.leadership.ng/business

[5]. Martin, E. (2014). Women in construction: Quantity Surveying. Accessed 4th June, 2014

[6]. National Bureau of Statistics (2010), National Manpower Stock and Employment GenerationSurvey: the Distribution of Employed Persons by Economic Activity and Gender

[7]. Nicholas, C. \& Theodore, C. (2010).An empirical analysis of factors impacting career decisionsin which African construction industry male and female high school students perspectives in Engineering. Journal of Engineering, Design and Technology, Vol. 8, Issue 2, pp 221-239.

[8]. Nigerian Institute of Quantity Surveyors (2011). The Constitution of The Nigerian Institute of Quantity Surveyors, 2011 (AS AMMENDED)

[9]. Nigerian Institute of Quantity Surveyors (2016), The Report of 2015-2017 National Executive Council.

[10]. Nigerian Institute of Quantity Surveyors (2016), Membership Strength by Grade and Gender:Nigerian Institute of Quantity Surveyors (2016). The History of Nigerian Institute of Quantity Surveyors Http://www.niqs.org.ngNigerian Soceity of Engineers, (2015), Past Presidents Http://www.nse.org.ng

[11]. Ojo, M. O. (1997), The Differential Effectiveness of Comparative and Individualistic ClassroomInteraction: Patterns on Students Chemical Problem Solving Skill. The Nigerian Teacher Today. 1 (2).

[12]. Otokhure H. (2016), Babalola becomes first female QS chairman. Accessed 27/3/2016Retrieved from Http://www.guardianngr.com

[13]. Royal Institution of Chartered Surveyors, (2015). 'President Louise Brook Smith namedOutstanding' www.birminghampost.co.uk.business, Accessed 30th March, 2015

[14]. Royal Institution of Chartered Surveyors (2015), Women in Surveying (1920 -date), Http://www.rics.orgSmith, R. C. (1988). Estimating and Tendering for Building Work. 2nd Edition. Longman Scientific and Technical. Patunola-Ajayi, B. J. (2016), From the President's Desk Http://www.niesv.org.ng

[15]. Skeggs, B. (1997), African Gender Theory. Http://en.wikipedia.org.wiki (2016), Isoko

[16]. United Nations Women, World Conferences on Women. www.UNwomen.org

[17]. Williams, K. (1991), Fast Track Route to Change, Chartered Quantity Surveyor, pp 13

[18]. www.architecture.com/RIBA/Aboutus/Whoweare/Ourhistory, Our History,Charter,and Byelaws.

[19]. Www.google.com.ng, Past Presidents of RIBAwww.rias.org.uk. Past Presidents

[20]. www.bradymallalieu.com. Past Presidents of RIBA

[21]. Www.archtecture.com (2014), Jane Duncan Elected next President of RIBA. Accessed 23rd July, 2014.

[22]. Www.ngex.com (2016), List of Practicing Firms in Lagos 